Original Research Paper

\title{
Intracellular L-Asparaginase from Bacillus sp. PG02: Purification, Biochemical Characterization and Evaluation of Optimum pH and Temperature
}

\author{
${ }^{1}$ Fatemeh Izadpanah Qeshmi, ${ }^{1}$ Mahsa Rahimzadeh, ${ }^{2}$ Sedigheh Javadpour and ${ }^{1}$ Manijeh Poodat \\ ${ }^{1}$ Molecular Medicine Research Center, Department of Biochemistry, \\ Faculty of Medicine, Hormozgan University of Medical Sciences, Bandar Abbas, Iran \\ ${ }^{2}$ Molecular Medicine Research Center, Department of Microbiology, \\ Faculty of Medicine, Hormozgan University of Medical Sciences, Bandar Abbas, Iran
}

Article history

Received: 26-08-2015

Revised: 16-11-2015

Accepted: 18-11-2015

Corresponding Author:

Mahsa Rahimzadeh

Molecular Medicine Research

Center, Department of

Biochemistry, Faculty of

Medicine, Hormozgan

University of Medical Sciences,

Emam Hossein Boulevard,

Bandar Abbas, Iran

P.O. Box: 7919693116

Tel; +98-761-6688024

Fax: +98-761-6668478

Email: m.rahimzadeh@hums.ac.ir

mahsa_rahimzadeh@yahoo.com

\begin{abstract}
Bacterial L-asparaginases are amidohydrolases that act on Lasparagine and produce L-aspartate and ammonia. These enzymes have been used in treatment of lymphoblastic leukemia. In the present study, a novel strain, Bacillus sp. PG02 was explored for the production of intracellular L-asparaginase enzyme. The nitrogen source for L-asparaginase production was L-asparagine. New intracellular L-asparaginase was purified using ion exchange chromatography and the purity was assessed using SDS-PAGE. Kinetic parameters $k_{m}$ and $V_{\max }$ and thermal properties were studied using L-asparagine as the substrate. SDS-PAGE analysis showed apparent molecular weight of approximately $38 \mathrm{kDa}$. The enzyme was active in a wide $\mathrm{pH}$ ranges (5-10) and it was maximally active at $\mathrm{pH}$ 7.5. Bacillus $\mathrm{PG} 02 \mathrm{~L}$-asparaginase was optimally active at $40^{\circ} \mathrm{C}$. Thermal inactivation studies exhibited $t_{1 / 2}$ of $32.5 \mathrm{~min}$ in $37^{\circ} \mathrm{C}$. Also $\mathrm{T}_{50}$ and $\Delta \mathrm{G}$ of inactivation were measured. The results revealed that the enzyme had appropriate characteristics and thus could be a potential candidate for medical and basic investigations.
\end{abstract}

Keywords: L-Asparaginase, Bacillus PG02, Thermal Stability, Kinetics

\section{Introduction}

L-asparaginase (EC.3.5.1.1; L-asparagine amidohydrolase) acts on L-asparagine as substrate and produces aspartate and ammonia. This enzyme is usually used for the treatment of acute lymphoblastic leukemia and non-Hodgkin lymphomas (Muller and Boos, 1998). The L-asparaginase anti-leukemic effect arises from the complete elimination of the circulating L-asparagine. Since most cancer cells are unable to produce asparagine, they are dependent on an exogenous source of this amino acid for survival (Miller et al., 1969). Normal cells are able to synthesize 1-asparagine, therefore less affects are seen in these cells upon treatment by L-asparaginase enzyme. Protein synthesis would be impaired in tumor cells because of asparagine deficiency and this would be followed by inhibition in DNA and RNA synthesis (Verma et al., 2007). Hence tumor cell functions impairs, which results in cell death (Gentili et al., 1996). In fried and oven-cooked foods such as potato chips, formation of acrylamide is probable. L-asparaginase enzyme can be used to reduce this reaction. Since, acrylamide formation in heated foods is mainly due to the reaction of free asparagine and reducing sugars, deamination of asparagine prevents acrylamide formation (Oza et al., 2011; Friedman, 2003). L-asparaginase is widely distributed among microorganisms, plants and animals (Mishalska et al., 2006; El-Bessoumy et al., 2004) but it has been proved that microorganisms are better source for producing Lasparaginase due to their economic production, ease of optimization and purification and large-scale production (Ferrara et al., 2006; Geckil et al., 2004; Kumar et al., 2011a). So far different aspects of the L-asparaginase activity like thermal stability and their optimum $\mathrm{pH}$ and temperature have been investigated but most of them did not show an appropriate condition for use as therapeutic agent. For instance, purification and characterization of L-asparaginase from Cladosporium $s p$. was reported. The enzyme was optimally active at $\mathrm{pH} 6.3$ the optimum temperature of the enzyme activity was $30^{\circ} \mathrm{C}$ (Mohan Kumar and Manonmani, 2013). L-asparaginase 
produced by Aspergillusterreus and Bacillus licheniformis RAM-8 were bothoptimally active at $\mathrm{pH}$ 9.0 and $40^{\circ} \mathrm{C}$ (Mahajan et al., 2014; Loureiro et al., 2012) and the enzyme from Pectobacteriumcarotovorum MTCC showed optimum $\mathrm{pH}$ and temperature of 8.5 and $40^{\circ} \mathrm{C}$ (Kumar et al., 2011b). Although there are different reports about L-asparaginase producing microorganisms, but the enzyme from Erwinia chrysanthemi and Escherichia coli are clinically used (Mashburn and Wriston, 1964; North et al., 1969). Unfortunately, some evidences of toxicity are shown by patients. Allergic responses happen as side effects and the use of Lasparaginases from other organisms can reduce this effect (Narta et al., 2007). Therefore, novel sources of the enzymes could be beneficial, providing an alternative anti-tumor agent with fewer side effects. In this study purification and characterization of intracellular L-asparaginase was performed. This enzyme is produced by a novel Bacillus PG02 (NCBI accession number: KF150761) isolated from Persian Gulf (Qeshmi et al., 2014). We have studied kinetic and thermal parameters including $\mathrm{t}_{1 / 2}, \mathrm{~T}_{50}$ and $\Delta \mathrm{G}^{*}$ of the enzyme. Also optimum $\mathrm{pH}$ and temperature of the enzymatic activity have been evaluated.

\section{Materials and Methods}

\section{Chemicals}

L-asparagine, Trichloroacetic acid (TCA), Sodium Dodecyl Sulfate (SDS), Nessler reagent chemicals (HgI2, KI and sodium hydroxide) and Tris were purchased from Sigma (St. Louis, MO, USA). DEAE Cellulose was obtained from Pharmacia (Uppsala, Sweden). All other chemicals were of analytical grade.

\section{Bacterial Strain, Growth Media and Culture Conditions}

The Bacterial strain used in this study was Bacillus PG02 (Accession number: KF150761). This strain was previously isolated from coastal location in north of Persian Gulf (Hormozgan province), Iran and identified based on nucleotide sequence of $16 \mathrm{~S} \quad r R N A$ gene (Qeshmi et al., 2014). The strain was maintained on Nutrient agar media at $37^{\circ} \mathrm{C}$ for $24 \mathrm{~h}$. The grown culture were stored at $4^{\circ} \mathrm{C}$ and subcultured monthly. Lasparaginase production by Bacillus PG02 was carried out in M9 medium including: Maltose $20 \%$ as a sole carbon source; $\mathrm{Na}_{2} \mathrm{HPO}_{4}$ 6.0(g/L); $\mathrm{KH}_{2} \mathrm{PO}_{4} 3(\mathrm{~g} / \mathrm{L})$; $\mathrm{NaCl} \quad 0.5(\mathrm{~g} / \mathrm{L}) ; \quad \mathrm{CaCl}_{2} \quad 0.011(\mathrm{~g} / \mathrm{L}) ; \quad \mathrm{MgSO}_{4} .7 \mathrm{H}_{2} \mathrm{O}$ $0.12(\mathrm{~g} / \mathrm{L}) ; \mathrm{pH} 7.0(\mathrm{~g} / \mathrm{L})$. The inoculum was prepared by adding a loop full of $24 \mathrm{~h}$ old pure culture grown on slant into $10 \mathrm{ml}$ of sterile medium in a $100 \mathrm{ml}$ Erlenmeyer flask. The culture flask was incubated at $37^{\circ} \mathrm{C}$ and $180 \mathrm{rpm}$ in an orbital shaking incubator for 10-12 h. Following growth until the midlogarithmic phase (OD at $600 \mathrm{~nm}=0.6-0.8$ ), the culture was inoculated $(2 \% \mathrm{v} / \mathrm{v})$ into a flasks containing production medium (100 in $500 \mathrm{~mL}$ flasks). Incubation was carried out at $37^{\circ} \mathrm{C}$ at $180 \mathrm{rpm}$ for $24 \mathrm{~h}$ (Qeshmi et al., 2014).

\section{Cell Disruption by Ultra-Sonication}

The ultra-sonication was used to prepare the intracellular L-asparaginase extract. After $24 \mathrm{~h}$ inoculation, cells were harvested by centrifugation at $8000 \times \mathrm{g}\left(4^{\circ} \mathrm{C}\right)$ for $10 \mathrm{~min}$. Cells were washed once with $50 \mathrm{Mm}$ Tris buffer ( $\mathrm{pH}$ 7.5) and suspended in

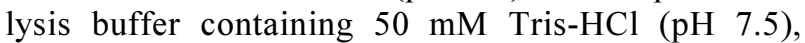
PMSF (1mM final concentration) and 5\% glycerol. The cells were cooled on ice and were ultra-sonicated at $20 \mathrm{MHz}, 40 \%$ amplitude, thirty times $10 \mathrm{sec}$ ultrasonic pulses at $15 \mathrm{sec}$ intervals (Ultrasonic processors $750 \mathrm{~W}$, Sigma-Aldrich, Germany). The lysate was centrifuged at $15,000 \times \mathrm{g}$ for $10 \mathrm{~min}\left(4^{\circ} \mathrm{C}\right)$. The clear supernatant was used as the enzyme source.

\section{Ammonium Sulfate Precipitation}

All precipitation steps were performed at $0-4^{\circ} \mathrm{C}$. After ultra-sonication, finely powdered ammonium sulfate was added to the clear supernatant with constant stirring and incubated overnight. Maximum Lasparaginase precipitation observed at $70-80 \%$ saturation. Centrifugation was performed $(10,000 \times \mathrm{g})$ for $30 \mathrm{~min}$ to collect the precipitate. The precipitate was then dissolved in a minimal amount of $50 \mathrm{mM}$ Tris- $\mathrm{HCl}$ buffer $(\mathrm{pH} 9)$ and dialyzed against the same buffer for $24 \mathrm{~h}$.

\section{DEAE Cellulose Chromatography and Molecular Weight Determination}

All purification steps were performed at $0-4{ }^{\circ} \mathrm{C}$. OD $280 \mathrm{~nm}$ was measured for all chromatographic eluted samples to monitor protein.

About $50 \mathrm{mM}$ Tris- $\mathrm{HCl}(\mathrm{pH}$ 9) used as equilibrium buffer and the sample was loaded on equilibrated diethylaminoethyl (DEAE) cellulose column $(4 \times 60 \mathrm{~cm})$. The column was washed with two column volume of the equilibrium buffer and the protein was eluted using a gradient of $\mathrm{NaCl}(50-1000 \mathrm{mM})$ in $50 \mathrm{mM}$ Tris- $\mathrm{HCl}(\mathrm{pH}$ $9)$. The active fractions were collected, dialyzed in Tris$\mathrm{HCl}(50 \mathrm{mM}$ and $\mathrm{pH} 7.5)$ and concentrated in $4{ }^{\circ} \mathrm{C}$ using centrifugal concentrator (Vivaspin 15, cut-off $5 \mathrm{kDa}$ ) according to the manufacturer. About $10 \mathrm{~mL}$ active fractions were added to the concentrator and centrifugation was performed until the final volume of $500 \mu \mathrm{L}$ was reached. This preparation was used in the subsequent steps. SDS-PAGE was performed using $10 \%$ separating acrylamide gel ( $\mathrm{pH} 8.8)$ and a 4\% stacking gel ( $\mathrm{pH}$ 6.8). Separated proteins in the gel were stained with Coomassie Brilliant Blue R-250. Standard molecular weight markers were used to determine approximate molecular weight of L-asparaginase (Laemmli, 1970). 


\section{Enzyme Activity, Protein Concentration and Enzyme Kinetics}

L-asparaginase activity was measured by the known method of (Imada et al., 1973). The purified enzymes fractions were mixed with $40 \mathrm{mM}$ L-asparagine dissolved in $50 \mathrm{mM}$ Tris-HCl buffer, $\mathrm{pH}$ 7.5. Enzymatic reaction was measured after incubation for $15 \mathrm{~min}$ at $37^{\circ} \mathrm{C} .250 \mu \mathrm{L}$ of $1.5 \mathrm{M}$ Trichloro acetic acid (TCA) was added to stop the reaction and the reaction mixture was centrifuged at $10,000 \times \mathrm{g}$ for $5 \mathrm{~min}$ at $4^{\circ} \mathrm{C}$ before the addition of Nessler's reagent to measure the released ammonia after L-asparagine hydrolysis. Absorbance was measured at $450 \mathrm{~nm}$ (spectrophotometer UV/Vis Unico, USA). One unit of L-asparaginase activity was defined as the amount of enzyme that released $1 \mu \mathrm{mol}$ of ammonia (with $10 \mu \mathrm{M}-10 \mathrm{mM}$ ammonium sulfate as the standard) per minute under the assay conditions specified. Protein concentration was also measured using bovine serum albumin as the standard (Bradford, 1976). In order to determine kinetic constants for Lasparaginase, measurements were carried out over different substrate concentration including 10, 20, 30, 40 and $80 \mathrm{mM}$ and the final concentration of the enzyme was $0.2 \mathrm{mg} \mathrm{mL}^{-1}$. Different blanks were used for each L-asparagine concentration. Kinetic parameters, $K_{m}$ and $V_{\max }$ for L-asparaginase enzymes were determined from a series of initial rates. Experimental data were analyzed graphically and numerically using the Lineweaver-Burk equation.

\section{Effects of $\mathrm{pH}$ and Temperature on L-asparaginase Activity}

The $\mathrm{pH}$ profile was determined at room temperature in various $\mathrm{pH}$ using $0.5 \mathrm{mg} \mathrm{mL} \mathrm{m}^{-1}$ of enzyme solution. The buffers used in this study were potassium phosphate (50 mM, pH 5-7.5) and Tri-HCl (50 mM, pH 8.0-10). The activity of purified enzyme was determined at several temperatures (from 25 to $50^{\circ} \mathrm{C}$ ) in $50 \mathrm{mM}$ Tris$\mathrm{HCl}$ buffer, $\mathrm{pH}$ 7.5.

\section{Thermal Stability Assay}

Half-lives were determined at two temperatures (37, $\left.40^{\circ} \mathrm{C}\right)$. For half-life measurement, $0.5 \mathrm{mg} \mathrm{mL}^{-1}$ enzyme solution in $50 \mathrm{mM}$ Tris-HCl buffer $(\mathrm{pH} \mathrm{7.5)}$ was used. $10 \mu \mathrm{L}$ aliquots of the enzyme solution were prepared and incubated for various time intervals. Then each sample was chilled on ice for $60 \mathrm{~min}$ and diluted into $20 \mu \mathrm{L}$ of an assay solution (L-asparagine $40 \mathrm{mM}$ ) for the measurement of residual activity at $37^{\circ} \mathrm{C}$ for $15 \mathrm{~min}$. Plots of the $\log$ of residual activity versus time were drawn to determine the order of the inactivation reaction. The plots were linear indicating first-order decay. Another parameter which gives information about thermal stability was $T_{50}$ which is the temperature of incubation at which $50 \%$ of the initial enzyme activity is lost during $30 \mathrm{~min}$ incubation (Rahimzadeh et al., 2012). Temperatures from 30 to $50^{\circ} \mathrm{C}$ were used for $\mathrm{T}_{50}$ measurements. The $\Delta \mathrm{G}^{*}$ parameter of the Lasparaginase enzyme was determined as follows (Rahimzadeh et al., 2012):

$$
\Delta \mathrm{G} *=\mathrm{RT} \ln (\mathrm{kBT} / \mathrm{h})-\mathrm{RT} \ln \mathrm{k}
$$

\section{Results and Discussion}

\section{L-asparaginase Purification and Molecular Weight Determination}

Most of the microbial L-asparaginases are intracellular enzymes in nature. Intracellular Lasparaginase was harvested from Bacillus PG02 by sonication and bacterial cell disruption. The purification steps of L-asparaginase are given in Table 1. After each step of purification, the specific activity of the enzyme increased. Specific activity of the purified enzyme after ion exchange step was $17.1 \mathrm{U} / \mathrm{mg}$ (Table 1). In DEAE-Cellulose anion-exchange chromatography step, total proteins of the eluted fractions were monitored at $280 \mathrm{~nm}$ and $\mathrm{L}$-asparaginase activity was measured by nesslerization. Figure 1a shows the eluted fractions that had L-asparaginase activity. Samples were pooled, dialyzed and concentrated by ultrafiltration. After purification procedure, SDS-PAGE was performed for the fractions with the enzyme activity. The estimated molecular weight of the purified enzyme was $38 \mathrm{kDa}$. Figure $1 \mathrm{~b}$. However, exact estimation of the L-asparaginase enzymes needs to be evaluated by native page, because most of these enzymes have oligomer structures.

\section{Effect of $\mathrm{pH}$ and Temperature on L-Asparaginase Activity}

$\mathrm{pH}$ and temperature of enzyme incubation with the substrate is one of the important factors which influences the enzymatic reaction rates. The optimum $\mathrm{pH}$ and temperature of the enzyme is usually beyond which the reduction in activity is observed. Here, activities of the enzyme were determined in a pH range from 5 to 10 . The results showed that Bacillus PG02 L-asparaginase was active over broad $\mathrm{pH}$ ranges from 5 to 10 . The enzyme activity gradually increased until $\mathrm{pH} 7.5$ at which the maximum activity was observed (Fig. 2a). This result showed that the optimum $\mathrm{pH}$ of the enzyme activity was near to that of the growth condition. There are very few reports in which the L-asparaginase enzymes showed optimum $\mathrm{pH}$ near physiologic $\mathrm{pH}$ range. Alkaline $\mathrm{pH}$ optima (8.0-9.0) were shown by the majority of L-asparaginases from Erwinia sp. whereas the enzyme from $E$. coli exhibited an acidic $\mathrm{pH}$ optimum 
of 5.0-6.0 (Capizzi et al., 1971; Whelan and Wriston, 1969). Currently, L-asparaginase enzyme produced by Erwinia carotouora is used for acute lymphoblastic leukemia treatment (Gentili et al., 1996; North et al., 1969). However, Kamble et al. (2006) found that the optimum $\mathrm{pH}$ of the enzyme from E.carotouora was 8.6. Our results revealed that the L-asparaginase produced by Bacillus PG02 was maximally active at $\mathrm{pH} 7.5$ which is near to the physiologic $\mathrm{pH}$. Since the physiological optimum $\mathrm{pH}$ is one of the main requirements for antitumor activity (Mannan et al., 1995), hence this desirable characteristic makes the enzyme suitable and attractive for both the structure-function research studies and the industrial and pharmacological processes.

A

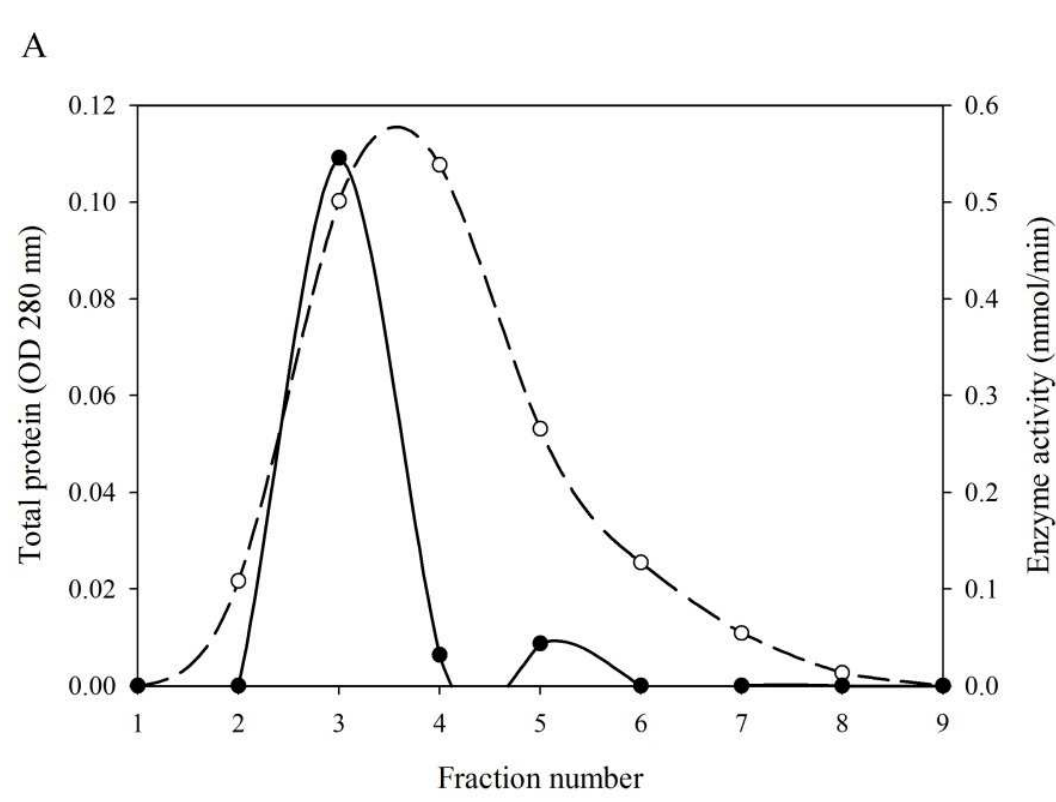

Similarly, the optimum temperature of the activity of L-asparaginase was studied in 20 to $50^{\circ} \mathrm{C}$ at $5^{\circ} \mathrm{C}$ intervals. Maximum activity was obtained at $40^{\circ} \mathrm{C}$ (Fig. 2b). However the enzyme was active at a wide range of temperatures from 30 to $45^{\circ} \mathrm{C}$ and was nearly $90 \%$ active in $37^{\circ} \mathrm{C}$. This property makes the enzyme more suitable for complete elimination of asparagine in patients suffering from leukemia. Mannan et al. (1995) found $37^{\circ} \mathrm{C}$ to be the optimum temperature for the enzyme activity. Mesas et al. (1990) reported $40^{\circ} \mathrm{C}$ as the optimum temperature of the L-asparaginase from Corynebacterium glutamicum. Also Jia et al. (2013) reported L-asparaginase enzyme produced from Bacillus subtilis B11-06 with similar optimum $\mathrm{pH}$ and temperature.

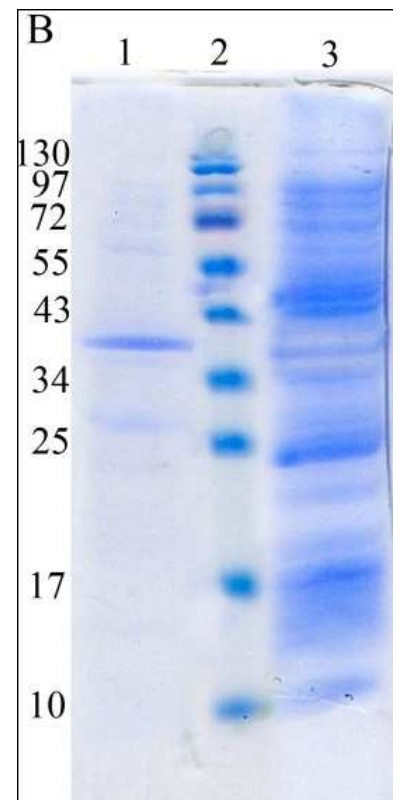

Fig. 1. Ion exchange chromatography and SDS-PAGE of L-asparaginase. The crude enzyme extract was chromatogrophed on DEAE-cellulose. Total protein was monitored at $280 \mathrm{~nm}$, (A) Dashed chromatogram represents OD $280 \mathrm{~nm}$, Solid chromatogram represents enzyme activity, (B) SDS-PAGE of the purified L-asparaginase. Bacillus PG02 L-asparaginase after purification (lane 1), Molecular weight marker (lane 2), L-asparaginase crude enzyme extract (lane 3)
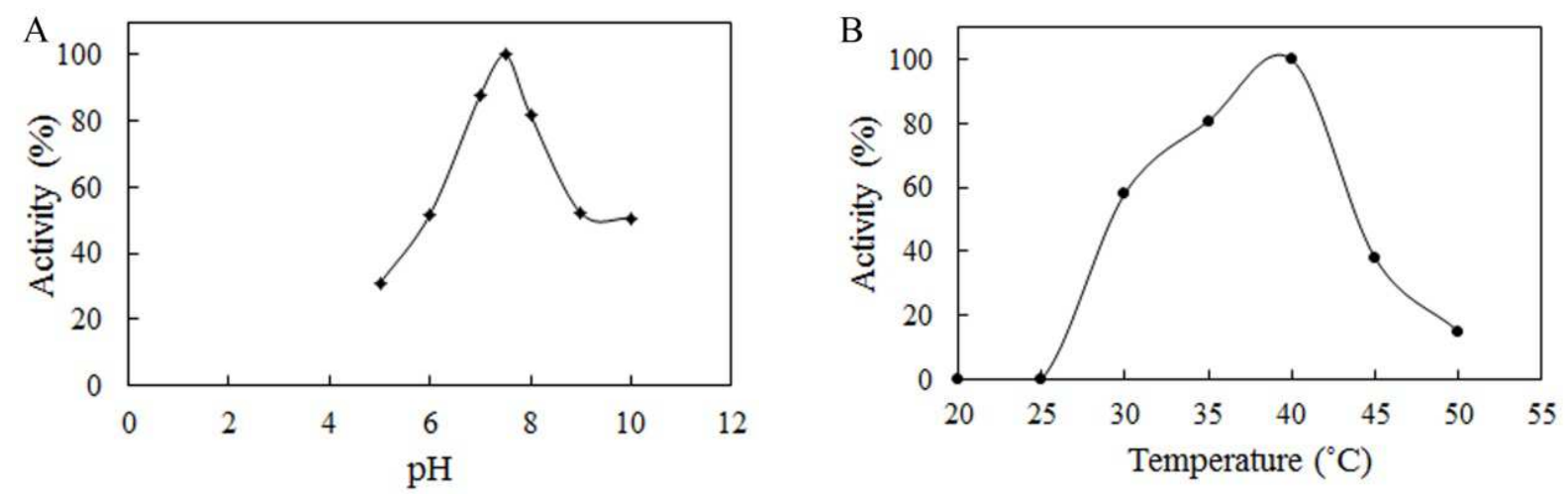

Fig. 2. (A) Effect of pH and (B) temperature on activity of Bacillus PG02 L-asparaginase. Optimum pH was determined by assaying the enzyme activity at various pHs (5 to 10 using $50 \mathrm{mM}$ potassium phosphate and $50 \mathrm{mM}$ Tris- $\mathrm{HC} 1$ at room temperature. Optimum temperature was determined at 25 to $50^{\circ} \mathrm{C}$ in $50 \mathrm{mM}$ Tris- $\mathrm{HCl}$ buffer, $\mathrm{pH} 7.5$ 


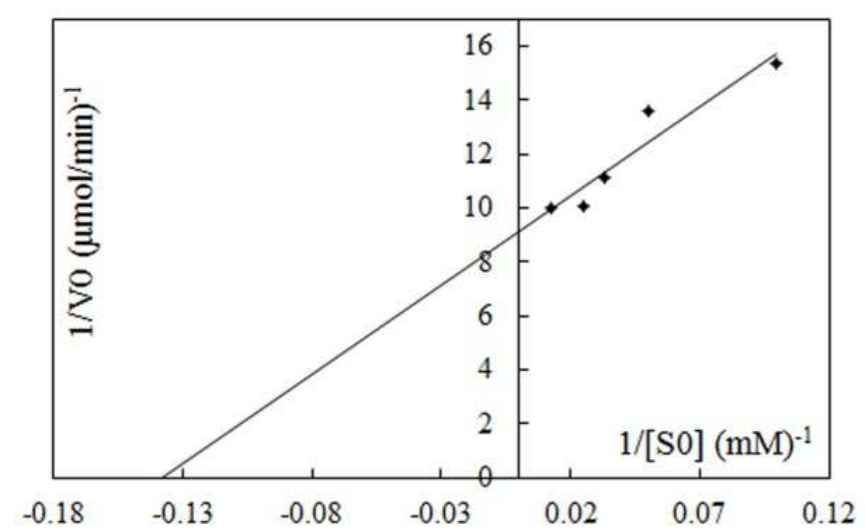

Fig. 3. Lineweaver-Burk plot of L-asparaginase activity. Five different concentrations of L-asparagine were used
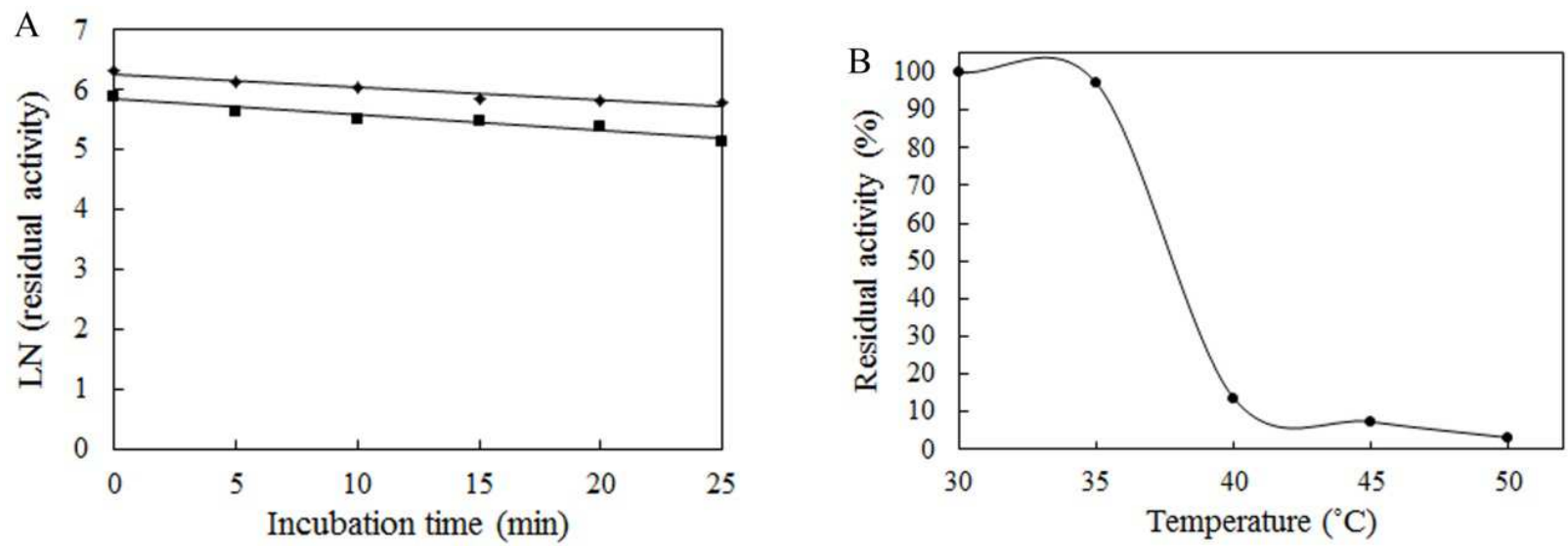

Fig. 4. Thermal stability studies of the L-asparaginase from Bacillus $P G 02$, (A) Half-life curves at $37^{\circ} \mathrm{C}$ (closed diamonds) and $40^{\circ} \mathrm{C}$ (closed squares)using $0.5 \mathrm{mg} \mathrm{mL}^{-1}$ enzyme solution in $50 \mathrm{mM}$ Tris- $\mathrm{HCl}$ buffer (pH 7.5), (B) T50 curve of the L-asparaginase after enzyme incubation at different temperatures $\left(30\right.$ to $\left.50^{\circ} \mathrm{C}\right)$ using in $50 \mathrm{mM}$ Tris- $\mathrm{HCl}$ buffer $(\mathrm{pH} 7.5)$

Table 1. Purification of L-asparaginase from Bacillus PG02

\begin{tabular}{|c|c|c|c|c|c|}
\hline Steps & $\begin{array}{l}\text { Total } \\
\text { activity (U) }\end{array}$ & $\begin{array}{l}\text { Total } \\
\text { protein }(\mathrm{mg})\end{array}$ & $\begin{array}{l}\text { Specific activity } \\
\left(\mathrm{U} \mathrm{mg}^{-1}\right)\end{array}$ & $\begin{array}{l}\text { Fold } \\
\text { purification }\end{array}$ & Yield $(\%)$ \\
\hline Crude extract & 91.3 & 50.3 & 1.8 & 1.0 & 100.0 \\
\hline (NH4)2SO4 precipitation & 74.2 & 34.2 & 2.2 & 1.2 & 81.3 \\
\hline DEAE cellulose column & 41.1 & 2.4 & 17.1 & 9.4 & 45.0 \\
\hline
\end{tabular}

Table 2. Kinetic constants and the thermostability parameters of the enzyme

\begin{tabular}{|c|c|c|c|c|c|c|c|c|}
\hline Enzyme & $K_{m}{ }^{a}(\mathrm{mM})$ & $\begin{array}{l}V_{\max }^{a} \\
(\mu \mathrm{mol} / \mathrm{min})\end{array}$ & $p H^{b}$ & $T_{o p t}^{c}\left({ }^{\circ} \mathrm{C}\right)$ & $T^{c}{ }_{50}\left({ }^{\circ} \mathrm{C}\right)$ & $\begin{array}{l}t^{d}{ }_{1 / 2} 37^{\circ} \mathrm{C} \\
(\min )\end{array}$ & $\begin{array}{l}t_{1 / 2}^{d} 40^{\circ} \mathrm{C} \\
(\min )\end{array}$ & $\begin{array}{l}\Delta \mathrm{G}^{* \mathrm{~d}} \\
(\mathrm{kcal} / \mathrm{mol})\end{array}$ \\
\hline Bacillus PG02 & 7.2 & 0.11 & 7.5 & 40 & 39 & 32.5 & 26.5 & 4.97 \\
\hline
\end{tabular}

Values are the averages of three experiments,

a Standard errors are less than \pm 0.07 .

$\mathrm{b}$ The error margin amounts to approximately 0.5 .

c The standard errors are less than \pm 1 .

d Standard errors are less than \pm 0.5 .

\section{Kinetic Properties of the Enzyme}

L-asparagine was used as the substrate for determining activity of the L-asparaginase enzyme. The enzyme revealed Michaelis-Menten kinetics. Based on the Line weaver-Burk analysis $K_{m}$ and $V_{\max }$ values for Lasparagine was $7.2 \mathrm{mM}$ and $0.11 \mu \mathrm{mol} / \mathrm{min}$, respectively (Table 2 and Fig. 3). Different substrate affinities have been reported for L-asparaginases from different microorganisms and therefore these enzymes probably 
played different physiological roles. Higher and lower $K_{m}$ values have been reported for different Lasparaginase enzymes (El-Bessoumy et al., 2004).

\section{Thermal Stability Properties}

In order to measure the heat inactivation rate constant of L-asparaginase, the enzyme aliquots were incubated at desirable temperatures and then were cooled on ice before measurement of the residual activity (Declerck et al., 1997; Kumar et al., 2011a). After incubation at 37 and $40^{\circ} \mathrm{C}$, the half-lives $\left(t_{1 / 2}\right)$ of Bacillus PG02 L-asparaginase were measured (Table 2). $k_{i}$ (inactivation rate constant) values were estimated from the plots of Log of residual activity versus incubation time. As is shown in Fig. 4a, inactivation process was a first order decay. Although the optimum temperature of the enzyme activity was $40^{\circ} \mathrm{C}$, but the enzyme showed higher half-life in $37^{\circ} \mathrm{C}$ compared to $40^{\circ} \mathrm{C}$. Bacillus $\mathrm{PG} 02$ L-asparaginase half-life was showed to be $32.5 \mathrm{~min}$ in $37^{\circ} \mathrm{C}$. In $40^{\circ} \mathrm{C}$ still the enzyme was active, although the reduction in half-life of the enzymes was clearly observed compared to $37^{\circ} \mathrm{C}$. This means that although the optimum activity of the enzyme occurs in $40^{\circ} \mathrm{C}$, but the enzyme retains active for longer time in $37^{\circ} \mathrm{C}$. Since the normal body temperature is near $37^{\circ} \mathrm{C}$, this could be an appropriate characteristic of Bacillus PG04 L-asparaginase enzymes for future uses. In naturally occurring enzymes the highest stability could be seen at temperatures near that of growth of an organism. This results from the relationship between conformational stability and enzyme activity (Kumar et al., 2011b; Daniel, 1996). Together these results showed that the purified enzyme could be regarded as an interesting target for thermal stability improvement investigations. Another criterion of thermal stability is $T_{50}$. The results of the $T_{50}$ measurements showed that the enzyme retained $50 \%$ of its activity after $30 \mathrm{~min}$ incubation in $39^{\circ} \mathrm{C}$ (Fig. $4 \mathrm{~b}$ and Table 2). This is consistent with the results of half-life studies. Free energy changes of inactivation $\left(\Delta \mathrm{G}^{*}\right)$ was evaluated using the inactivation rate constant at $37^{\circ} \mathrm{C} . \Delta \mathrm{G}^{*}$ value of inactivation indicates the distance between the native state and the transition state and is a benchmark of the required input energy for enzyme inactivation (Table 2).

\section{Conclusion}

Bacillus PG02 L-asparaginase had several beneficial properties required for a therapeutic and industrial enzyme. The enzyme had a broad temperature range of activity with maximum activity at $40^{\circ} \mathrm{C}$ and at physiologic $\mathrm{pH}$. These features of the enzyme were very important for the future therapeutic uses. Kinetic properties of the enzyme showed that the enzyme had approximately appropriate affinity for L-asparagine.

On the other hand, thermal stability measurements showed that the enzyme could be a potential target for thermal stability improvement studies. Due to these characteristics, in our future studies, further enzymatic studies including glutaminase activity, structural analysis and determination of encoded gene sequence of this L-asparaginase will be carried out in order to understand the mechanism of its activity and to improve kinetic and stability properties of this therapeutic target by protein engineering methods. Although the enzyme from Bacillus subtilis B11-06 showed similar molecular weight and optimum $\mathrm{pH}$ and temperature (30), but thermal characteristics and kinetic properties $(\mathrm{Km})$ of that enzyme was different from the enzyme produced by Bacillus PG02. Anyway, $\mathrm{N}$-terminal sequencing of the enzyme could be beneficial to more clarify the differences of this enzyme with other similar enzymes.

\section{Acknowledgment}

The authors express the gratitude to the molecular medicine research center and research council of Hormozgan University of medical sciences, Iran, for the financial support. The results described in this paper were part of student thesis.

\section{Author's Contributions}

Mahsa Rahimzadeh: Developed the idea and wrote the manuscript.

Fatemeh Izadpanah Qeshmi and Manijeh Poodat: Performed the experiments.

Sedigheh Javadpour: Read and improved the manuscript and advised in experimental methods.

\section{Conflict of Interest}

The authors declare that they had no conflict of interest.

\section{References}

Bradford, M.M., 1976. A rapid and sensitive method for the quantitation of microgram quantities of protein utilizing the principle of protein-dye binding. Analytical Biochem., 72: 248-254. DOI: 10.1016/0003-2697(76)90527-3

Capizzi, R.L., J.R. Bertino, R.T. Skeel, W.A. Creasey and R. Zanes et al., 1971. L-Asparaginase: Clinical, biochemichal, pharmacological and immunological studies. Annals Internal Med., 74: 893-901. DOI: $10.7326 / 0003-4819-74-6-893$

Daniel, R.M., 1996. The upper limits of enzyme thermal stability. Enzyme Microbial. Technol., 19: 74-79. DOI: 10.1016/0141-0229(95)00174-3 
Declerck, N., M. Machius, R. Chambert, G. Wiegand and R. Huber et al., 1997. Hyperthermostable mutants of Bacillus licheniformis alpha-amylase: Thermodynamic studies and structural interpretation. Protein Eng., 10: 541-549. DOI: $10.1093 /$ protein/10.5.541

El-Bessoumy, A.A., M. Sarhan and J. Mansour, 2004. Production, isolation and purification of LAsparaginase from pseudomonas aeruginosa 50071 using solid-state fermentation. J. Biochemchem. Molecular Biol., 37: 387-393.

DOI: 10.5483/BMBRep.2004.37.4.387

Ferrara, M.A., N. Severino, J. Mansure, A.S. Martins and E.M. Oliveira et al., 2006. Asparaginase production by a recombinant Pichia pastoris strain harbouring Saccharomyces cerevisiae ASP3 gene. Enzyme Microbial. Technol., 39: 1457-1463.

DOI: $10.1016 /$ j.enzmictec.2006.03.036

Friedman, M., 2003. Chemistry, biochemistry and safety of acrylamide: A review. J. Agric. Food Chem., 51: 4504-4526. DOI: 10.1021/jf030204+

Geckil, H., S. Gencer and M. Uckun, 2004. Vitreoscilla hemoglobin expressing Enterobacter aerogenes and Pseudomonas aeruginosa respond differently to carbon catabolite and oxygen repression for production of 1-asparaginase, an enzyme used in cancer therapy. Enzyme Microbial. Technol., 35: 182-189. DOI: 10.1016/j.enzmictec.2004.04.005

Gentili, D., V. Conter, C. Rizzari B. Tschuemperlin and M. Zucchetti et al., 1996. L-Asparagine depletion in plasma and cerebro-spinal fluid of children with acute lymphoblastic leukemia during subsequent exposures to Erwinia L-asparaginase. Annals Oncolol., 7: 725-730.

DOI: 10.1093/oxfordjournals.annonc.a010722

Imada, A., S. Igarasi, K. Nakahama and M. Isono, 1973. Asparaginase and glutaminase activities of microorganisms. Microbiol., 76: 85-99. DOI: 10.1099/00221287-76-1-85

Qeshmi, F.I., S. Javadpour, K. Malekzadeh, S. TamadoniJahromi and M. Rahimzadeh, 2014. Persian Gulf is a bioresource of potent 1asparaginase producing bacteria: Isolation and molecular differentiating. Int. J. Environm. Res., 8: 813-818.

Jia, M., M. Xu, B. He and Z. Rao, 2013. Cloning, expression and characterization of L-asparaginase from a newly isolated bacillus subtilis B11-06. J. Agric. Food Chem., 61: 9428-9434. DOI: $10.1021 / \mathrm{jf4} 02636 \mathrm{w}$

Kamble, V.P., R. SrinivasaRao, P.S. Borkar, C.N. Khobregade and B.S. Daeane, 2006. Purification of L-asparaginase from a bacteria Erwinia carotovora and effect of a dihydropyrimidine derivative on some of its kinetic parameters. Ind. J. Biochem. Biophys., 43: 391-394. PMID: 17285805
Kumar, S., V.V. Dasu and K. Pakshirajan, 2011a. Studies on $\mathrm{pH}$ and thermal stability of novel purified L-asparaginase from Pectobacterium carotovorum MTCC 1428. Microbiology, 80: 355-362. DOI: $10.1134 / \mathrm{S} 0026261711030143$

Kumar, S., V.V. Dasu and K. Pakshirajan, 2011 b. Purification and characterization of glutaminase-free l-asparaginase from Pectobacterium carotovorum MTCC 1428. Bioresour Technol., 102: 2077-2082. DOI: $10.1016 /$ j.biortech.2010.07.114

Laemmli, U.K., 1970. Cleavage of structural proteins during the assembly of the head of bacteriophage T4. Nature, 227: 680-685. DOI: 10.1038/227680a0

Loureiro, C.B., K.S. Borges, A.F. Andrade, L.G. Tone and S. Said, 2012. Purification and biochemical characterization of native and pegylated form of 1asparaginase from Aspergillus terreus and evaluation of its antiproliferative activity. Adv. Microbiol., 2: 138-145. DOI: $10.4236 /$ aim.2012.22019

Mahajan, R.V., V. Kumar, V. Rajendran, S. Saran and C. Ghosh et al., 2014. Purification and characterization of a novel and robust l-asparaginase having lowglutaminase activity from Bacillus licheniformis: In vitro evaluation of anti-cancerous properties. Plos One, 9: 1-8. DOI: 10.1371/journal.pone.0099037

Mannan, S., A. Sinha, R. Sadhukhan and S.L. Chakrabarty, 1995. Purification, characterization and antitumor activity of 1-asparaginase isolated from Pseudomonas stutzeri MB-405. Current Microbiol., 30: 291-298. DOI: 10.1007/BF00295504

Mashburn, L.T. and J.C. Wriston, 1964. Tumor inhibitory effect of l-asparaginase from Escherichia coli. Archives Biochem. Biophys., 105: 450-452. DOI: 10.1016/0003-9861(64)90032-3

Mesas, J.M., J.A. Gil and J.F. Martin, 1990. Characterization and partial purification of 1asparaginase from Corynebacterium glutamicum. J. General Microbiol., 136: 515-519. DOI: $10.1099 / 00221287-136-3-515$

Miller, H.K., J.S. Salser and M.E. Balis, 1969. Amino acid levels following L-asparagine amidohydrolase (EC.3.5.1.1) therapy. Cancer Res., 29: 183-187. PMID: 5763976

Mishalska, K., G. Bujacz and M. Jaskolski, 2006. Crystal structure of plant asparaginase. J. Molecular Biol., 360: 105-116. DOI: $10.1016 /$ j.jmb.2006.04.066

Mohan Kumar, N.S. and H.K. Manonmani, 2013. Purification, characterization and kinetic properties of extracellular L-asparaginase produced by Cladosporium sp. World J. Microbiol. Biotechnol., 29: 577-587. DOI: 10.1007/s11274-012-1213-0

Muller, H.J. and J. Boos, 1998. Use of L-asparaginase in childhood ALL. Critical Rev. Oncol. Hematol., 28: 97-113. DOI: 10.1016/S1040-8428(98)00015-8 
Narta, U.K., S.S. Kanwar and W. Azmi, 2007. Pharmacological and clinical evaluation of Lasparaginase in the treatment of leukemia. Critical Rev. Oncol. Hematol., 61: 208-221.

DOI: $10.1016 /$ j.critrevonc.2006.07.009

North, A.C., H.E. Wade and K.A. Cammack, 1969. Physicochemical studies of l-asparaginase from Erwinia carotovora. Nature, 224: 594-595.

DOI: $10.1038 / 224594 \mathrm{a} 0$

Oza, V.P., P.P. Parmar, D.H. Patel and R.B. Subramanian, 2011. Cloning, expression and characterization of 1asparaginase from Withania somnifera $\mathrm{L}$. for large scale production. Biotechnology, 1: 21-26.

DOI: $10.1007 / \mathrm{s} 13205-011-0003-y$
Rahimzadeh, M., K. Khajeh, M. Mirshahi, M. Khayatian and R. Schwarzenbacher, 2012. Probing the role of asparagine mutation in thermostability of Bacillus KR-8104 $\alpha$-amylase. Int. J. Biological. Macromolecules, 50: 1175-1182.

DOI: $10.1016 /$ j.ijbiomac.2011.11.014

Verma, N., K. Kumar, G. Kaur and S. Anand, 2007. Lasparaginase: A promising chemotherapeutic agent. Critical Rev. Biotechnol., 27: 45-62. DOI: $10.1080 / 07388550601173926$

Whelan, H.A. and J.C. Wriston, 1969. Purification and properties of asparaginase from Escherichia coli B. Biochemistry, 8: 2386-2393.

DOI: $10.1021 / \mathrm{bi} 00834 \mathrm{a} 020$ 